Ritsýrð grein birt 31. desember 2021

\title{
Gagnagöt í spurningakönnunum meðal íslenskra unglinga
}

\author{
Hans Haraldsson og Ingibjörg Kjartansdóttir \\ Abstract $\longrightarrow$ Um höfunda $\longrightarrow$ About the authors $\quad$ Heimildir
}

Á Íslandi eru reglulega lagðar fyrir allmargar spurningakannanir um líðan unglinga, hegðun peirra, umhverfi, nám og starf. Spurningalistarnir í pessum könnunum eru gjarnan langir og fela stundum í sér krefjandi svarverkefni. Petta leiðir til hættu á kerfisbundnum gagnagötum sem geta bjagað niðurstöður. Í pessari grein eru gagnagöt í premur unglingakönnunum; ESPAD, HBSC og viðhorfa- og bakgrunnsspurningalista PISA-könnunarinnar greind út frá staðsetningu spurningar og spurningaformi. Вæði athuguðum við brottfall par sem svarandi hætti pátttöku áður en hann lauk við að svara listanum og gagnagöt sem hljótast af pví að svarendur hoppa yfir spurningar. Hlutfall gagnagata er töluvert í öllum könnunum en breytilegt eftir staðsetningu, formi og efni spurninga. ESPAD-spurningalistinn virðist heldur of langur og PISA-spurningalistinn allt of langur fyrir markhópa kannananna. Í HBSC má greina nokkuð skýr tengsl á milli spurningaforma og líkinda á að svar vanti, sérstaklega hjá yngri svarendum. Pað er of lítill breytileiki í spurningaformum í hinum könnununum til að hægt sé að greina áhrif spurningaforma frá áhrifum staðsetningar. Brottfall er minna úr HBSC en hinum könnununum, mögulega vegna pess að spurningaform eru fjölbreyttari. Gagnagöt vegna pess að svarendur hoppa yfir spurningar eru hins vegar ekki mikið færri pegar tillit er tekið til lengdar. Brottfall og tilhneiging til að hoppa yfir spurningar hefur skýr tengsl við kyn svaranda í öllum könnunum og bekk svaranda í HBSC. Í ESPAD má greina skýrt samband áhættuhegðunar sem spurt er um snemma í könnuninni við bæði líkur á að svarendur falli úr könnun og hoppi yfir spurningar. Pað eru pví nokkrar vísbendingar um að gagnagöt séu kerfisbundin og geti valdið umtalsverðum bjaga á niðurstöðum. Möguleikar á að stytta og einfalda kannanir eru teknir til umfjöllunar undir lok greinarinnar.

Efnisorð: Gagnagöt, HBSC, ESPAD, PISA

\section{Inngangur}

Spurningakannanir meðal unglinga á grunnskólaaldri um líðan peirra, hegðun, hagi, nám og starf hafa verið framkvæmdar reglulega á Íslandi undanfarna áratugi. Niðurstöður pessara kannana hafa birst í fjölmörgum vísindagreinum, auk pess sem pær hafa haft umtalsverða pýð̇ingu fyrir stefnumótun á sviði mennta- og æskulýðsmála. Par fer mest fyrir fimm könnunum. Árlega eru lagðar fyrir tvær kannanir, Ungt fólk og Skólapúlsinn, sem framkvæmdar eru af einkafyrirtækjunum Rannsóknum og greiningu og Vísum - Rannsóknum ehf. Prjár kannanir, 1) Evrópska vímuefnarannsóknin (European School Survey Project on Alcohol and Other Drugs, hér eftir ESPAD), 2) Alpjóðlega menntakönnunin (Programme for International Student Assessment, hér eftir PISA) og 3) Heilsa og lífskjör skólanema (Health Behaviour in School-aged Children, hér eftir HBSC) eiga pað svo sameiginlegt að vera lagðar fyrir með lengra millibili, vera hluti af fjölpjóðlegri gagnasöfnun meðal barna og unglinga sem skilað er inn í opinn aðgang (e. open access), og niðurstöður peirra par með mikið notaðar til fjölbjóðlegs samanburðar. Til viðbótar við pessar kannanir mætti telja upp margar fleiri, 
bæði litlar og stórar sem lifað hafa í lengri eða skemmri tíma, en í pessari grein verður sérstaklega fjallað um pessar prjár fjölpjóðlegu kannanir; ESPAD, HBSC og PISA.

ESPAD hefur verið lögð fyrir nemendur í 10. bekk á fjögurra ára fresti frá árinu 1995 (ESPAD, e.d.). Eins og nafnið gefur til kynna er par aðallega spurt um áfengis-, vímuefna- og tóbaksnotkun en par eru einnig spurningar par sem spurt er um fjölskylduaðstæður, bjargráð við vandamálum (e. coping) og net- og tölvuleikjanotkun sem búast má við að tengist fíknihegðun.

PISA hefur verið framkvæmd á priggja ára fresti frá árinu 2000 (Menntamálastofnun, e.d.) og á að leggja fyrir nær alla unglinga á aldrinum 15 ára og tveggja mánaða til 16 ára og priggja mánaða (OECD, 2019). Könnunin samanstendur af prófverkefnum sem eiga að meta lesskilning nemenda ásamt læsi á stærðfræði og náttúrufræði við lok skólagöngu auk spurningalista um fjölskyldu, heimilisaðstæður og bakgrunn nemenda, námsferil, námsvenjur, skólaumhverfi og ýmis viðhorf.

HBSC hefur verið framkvæmd á fjögurra ára fresti frá árinu 2006 (Póroddur Bjarnason o.fl., 2006) og er lögð fyrir nemendur í 6., 8. og 10. bekk grunnskóla. Í peirri könnun eru svarendur spurðir um áfengis-, vímuefna-, og tóbaksnotkun, andlega og líkamlega líðan og heilsu, mataræði, félags-, tómstunda- og ípróttastarf, fjölmiðla- og netnotkun, samskipti við foreldra, fjárhag fjölskyldu, nám og skólaumhverfi og margt fleira.

Spurningalistarnir í pessum premur könnunum eiga pað sameiginlegt að vera býsna langir. Lengd peirra spannar frá 148 spurningaliðum fyrir nemendur í 6. og 8. bekk í HBSC upp í 307 spurningaliði fyrir svarendur PISA-könnunarinnar. Almennt fá nemendur 35-40 mínútur til að svara. Augljóst er að ekki fást merkingarbær svör við spurningum nema að svarandi ráði við að lesa allar spurningarnar á peim tíma sem hann hefur, skilja pær og eigi auk pess tíma afgangs til að taka afstöðu til spurninganna og skrá svar sitt. Um leið eru spurningar á ólíkum formum. Til dæmis er í öllum spurningalistunum að finna blöndu af einföldum fjölvalsspurningum par sem einn svarkostur er valinn með að haka við, fjölvalsspurningum par sem velja má fleiri en einn svarkost, opnum spurningum par sem svarandi parf að skrifa inn orð eða tölur og spurningatöflum par sem svarandi parf að tengja saman dálka af svarkostum við raðir af spurningum (sjá nánar undir hugtakaskilgreiningum í aðferðarkafla). Svarandi parf eirð og einbeitingu til að ljúka verkefninu.

Pótt enginn vafi leiki á að dæmigerður íslenskur unglingur sem tilheyrir markhópum pessara kannana ráði auðveldlega við pað verkefni að svara spurningalista af pessu tagi er pað langt pví frá sjálfgefið að allir unglingar ráði vel við slíkt verkefni. Ef líkur eru á að gögn vanti og að vöntun sé háð peim breytum, sem við höfum áhuga á, er hætta á að niðurstöður verði verulega bjagaðar. Lestrarörðugleikar hafa til dæmis verið tengdir við vanlíðan (Livingston o.fl., 2018). Ef búið er að missa fjölda svarenda með verulega lestrarörðugleika út úr könnun við spurningu 100 og byrjað er að spyrja um vanlíðan í spurningu 101 skapast hætta á að við fáum bjagaða mynd af algengi tilfinningavanda. Stundum er hægt að laga slíkt með pví að aðlaga tölfræðigreiningu en alls ekki alltaf (sjá til dæmis Rubin, 1976). Fyrsta skrefið er pó alltaf að greina hvort einhver merki séu um vandamál.

Í pessari grein skoðum við gagnagöt í premur spurningakönnunum; ESPAD, HBSC og bakgrunnsog viðhorfaspurningalista PISA-könnunarinnar, eftir hópum svarenda, staðsetningu spurninga í lista og tegund spurningar. Kannanirnar sem hér eru skoðaðar eru ekki tilraunakannanir á sviði aðferðafræði. Gögnunum var pannig ekki safnað í peim tilgangi að aðskilja áhrif efnis, uppsetningar og staðsetningar spurningar á gagnagöt. Hver spurning er aðeins á einum stað og í einni uppsetningu. Ef svörun hrynur undir lok könnunar pá gæti pað verið vegna pess að spurningarnar par eru viðkvæmar eða leiðinlegar. Рað getur pó verið vísbending um að könnunin sé of löng. Ef svipað mynstur sést eftir jafn margar spurningar í öðrum könnunum erum við komin með sterkari vísbendingu um að pær fari allar fram úr polmörkum markhópsins. Sama á við ef gagnagötum fjölgar pegar spurningar eru á tilteknu formi (t.d. fjölkostaspurning eða spurningatafla). Gerist pað á einum stað gæti pað verið vegna pess að spurningin sé sérstaklega erfið eða einfaldlega leiðinleg. Ef pað gerist á mörgum stöðum erum við komin með vísbendingu um að formið hafi áhrif. 
Í pessari grein munum við pví bera saman gagnagöt og brottfall eftir staðsetningu og tegund spurningar í premur könnunum sem lagðar eru fyrir unglinga á grunnskólaaldri á Íslandi; HBSC, ESPAD og PISA, í peim tilgangi að skoða hvort fram komi gegnumgangandi mynstur.

\section{Аðferð}

\section{Gagnasöfn}

ESPAD: Hrágögn úr íslenskri fyrirlögn ESPAD 2019 voru greind.

Í ESPAD-rannsókninni tíðkast að pegar gögnum er skilað í alpjóðlega gagnagrunninn er fyllt upp í gagnagöt ef hægt er að ráða svarið við spurningu sem ekki hefur verið svarað út frá svari við annarri spurningu sem hefur verið svarað. Ef svarandi svarar til dæmis ekki spurningu um áfengisdrykkju um ævina en segist hafa drukkið áfengi síðustu 30 daga er fyllt inn í gatið pannig að í alpjóðlegu gögnunum telst hann hafa svarað spurningunni um áfengisdrykkju um ævina játandi. Einnig eru svarendur sem svara mjög fáum spurningum eða velja ósennilega oft svarmöguleika um mikla vímuefnanotkun hreinsaðir úr gögnunum. Greiningin hér er gerð á hrágögnum íslensku rannsóknarinnar eins og pau líta út fyrir hreinsun og áður en fyllt hefur verið inn í gagnagöt.

Skólaárið 2018-2019 voru 4430 nemendur í 10. bekk í grunnskólum á Íslandi. Samanlagður fjöldi nemenda í grunnskólum sem sampykktu pátttöku í ESPAD var 4011. Pó lögðu ekki allir skólar sem höfðu sampykkt pátttöku könnunina fyrir. Í skólum sem bæði sampykktu og skiluðu inn einhverjum svörum voru samtals 3378 nemendur. Úr pessum skólum bárust samtals 2745 svör fyrir gagnahreinsun. Par sem gagnagöt eru greind eftir kyni eru aðeins gögn frá svarendum sem svara spurningu um kyn notuð í greiningunni (sú spurning birtist fremst í spurningalistanum). Gögn frá 2609 svarendum í ESPAD voru greind.

Fyrirlögn ESPAD er ekki fullkomlega samræmd en könnuninni var alltaf svarað á skólatíma og langoftast í einni 40 mínútna kennslustund. Fyrirlögnin 2019 var fyrsta rafræna fyrirlögn ESPAD, en könnunin hafði fram að pví verið lögð fyrir á pappírsformi.

HBSC: Gögn úr íslenskri fyrirlögn HBSC 2018 voru greind.

Pegar HBSC 2018 var lögð fyrir lagði Reykjavíkurborg bann við að svör yrðu rekjanleg á einstaka skóla. Pað er pví ekki hægt að greina pátttöku eftir skólum með sama hætti og fyrir ESPAD. Nemendur í 6., 8. og 10. bekk á Íslandi voru 13241 árið 2018. 6946 svör bárust við könnuninni.

Gögn úr HBSC eru greind eftir kyni og bekk sem spurt er um í fyrstu tveimur spurningum listans og takmarkast greiningin pví við svarendur sem svöruðu peim spurningum. Boðið var upp á svarmöguleikann „Annað“ pegar svarendur voru spurðir um kyn en peir 118 svarendur sem völdu pann möguleika eru of fáir fyrir pær greiningar sem hér eru gerðar (32 svöruðu ekki um kyn).

Gögn frá 6796 svarendum í HBSC voru greind.

Líkt og í ESPAD var fyrirlögn HBSC ekki fullkomlega samræmd en spurningalistum var alltaf svarað á skólatíma og langoftast í einni 40 mínútna kennslustund. HBSC-könnunin var lögð fyrir rafrænt í fyrsta skipti 2018, en könnunin, eins og ESPAD, hafði fram að pví verið lögð fyrir á pappírsformi.

PISA: Greiningin á PISA-gögnum er unnin á gagnasafni sem er aðgengilegt á heimasíðu OECD. Samkvæmt aðferðarlýsingu OECD fer fyrirlögn pannig fram að svarendur taka tvær 60 mínútna próflotur með stuttu hléi (um pað bil fimm mínútur) á milli. Síðan fá peir annað hlé sem mælt er með að sé 15-30 mínútur og fá svo um pað bil 35 mínútur til að svara spurningalista um bakgrunn, aðstæður og viðhorf sem hér er skoðaður (OECD, e.d.). 
Á Íslandi er PISA-spurningalistinn lagður fyrir nær óstyttur (í öðrum löndum eru spurningatöflur stundum styttar út og nýjum spurningum stundum bætt við - til dæmis premur spurningatöflum ST801-ST803 í danska spurningalistanum). Sextíu og sex íslenskir svarendur sem svöruðu léttari prófbók (svokallaðri une-heure bók) og fengu styttan lista og eru ekki teknir með í greiningu hér.

Í íslenska PISA-gagnasafninu má finna svör pátttakenda við flestum spurningum. Nokkrar spurningar eru pó ekki aðgengilegar, væntanlega vegna persónuverndarsjónarmiða. Dæmi um slíkar spurningar eru fæðingardagur svaranda og svör við opnum spurningum um störf foreldra. Í greiningum hér voru pessar spurningar hafðar með pegar spurningar voru staðsettar í röð, en vitaskuld eru engin svarhlutföll reiknuð fyrir pær. Vöntunargildi töldust pau svör sem voru kóðuð „No Response“ eða „Missing“ eða svör sem voru tóm án frekari skýringa.

Fyrstu 3 spurningarnar í PISA-gagnasafninu eru ekki með neinum gagnagötum. Ekki tókst að finna skýringu á pví í lýsigögnum en par sem um mjög einfaldar bakgrunnsupplýsingar (kyn, fæðingardag og bekk) er að ræða verður að teljast líklegt að fyllt hafi verið í gagnagöt með skráargögnum skóla.

3296 pátttakendur svöruðu PISA-könnuninni á Íslandi og var svarhlutfall 87\% (Menntamálstofnun, 2019).

Pegar svarendur sem svöruðu léttari prófbók höfðu verið teknir frá stóðu eftir gögn frá 3230 svarendum við PISA-könnuninni.

\section{Tölfræðileg úrvinnsla}

Niðurstöður eru aðeins greindar myndrænt og með lýsandi tölfræði af fjórum meginástæðum. Í fyrsta lagi eru gagnasöfnin af peirri stærðargráðu að nær útilokað er að sýnileg mynstur sem koma endurtekið fram birtist fyrir hreina tilviljun. İ öðru lagi verða áhrif efnis aldrei mjög vel tölfræðilega aðgreind frá áhrifum staðsetningar og spurningaforms. Hver spurning í listunum situr alltaf í sama sæti og er alltaf á sama formi (opin eða lokuð, stök eða í töflu). Í priðja lagi er efni spurninganna ekki lýsandi pverskurður af efni kannanaspurninga og tæplega hægt að gera grein fyrir pví sem slembipætti. Sem dæmi myndi formlegt tölfræðilíkan til að setja nákvæma tölu á áhrifin af spurningatöfluframsetningu í sæti 100 líklega ekki skila mjög áreiðanlegri forspá um hvað myndi gerast á sama stað í annarri könnun. Í fjórða lagi hafa gagnagöt ekki verið greind með pessum hætti áður og pví skortir fræðilegan grundvöll fyrir mörgum ákvörðunum um hvernig formlegt líkan yrði tilgreint. Par sem hér er ekki rúm til að prófa margar útgáfur líkana og ræða ákvarðanir í smáatriðum er hætt við að nákvæmar tölur myndu á endanum að miklu leyti velta á huglægum og mögulega duldum ákvörðunum greinanda (sjá til dæmis Huntington-Klein o.fl., 2020). Um leið er hægt að álykta að verulegar líkur séu á að mynstur í nýjum gögnum verði keimlík peim sem sjást hér, sérstaklega ef pau eiga sér nærtækar orsakaskýringar og koma fram endurtekið.

Pegar myndrænar greiningar eru skoðaðar er rétt að hafa í huga að myndir sýna meðaltöl svarendahóps en ekki einstaklingsferla. Ef brottfall er til staðar breytist svarendahópurinn yfir könnunina, hópurinn sem lýkur könnuninni er ekki eins og sá sem hóf könnunina. Dæmi um pað hvernig petta gæti gerst er pegar við erum með spurningu sem útheimtir sérstaklega miklar kröfur um lesskilning (er sérstaklega erfið) myndum við eiga von á að svarendur með slakan lesskilning slepptu henni frekar og héldu áfram að svara könnuninni ef hún er í sæti 10 en 108. Рað er að segja að við myndum síður eiga von á að líkurnar á að svarandi sem er enn inni í könnuninni sleppi henni séu pær sömu ef hún birtist í sæti 180 frekar en sæti 10. Ástæðan er að við spurningu 180 kann brottfallið að hafa hreinsað út töluverðan hóp svarenda sem eiga við lestrarörðugleika að stríða auk pess sem preytuáhrif kunna að skilyrða áhrif efnis. Við eigum sem sagt ekki von á að sjá sömu áhrif á heildarmeðaltalið alls staðar í könnuninni. 


\section{Hugtakaskilgreiningar}

Birtingarskilyrði: Sumar spurningar eru pannig settar upp í rafrænni fyrirlögn að pær birtast aðeins ef svarandi svarar fyrri spurningum með tilteknum hætti. Pannig eru til dæmis spurningar í HBSC um hvar svarandi var staddur pegar hann varð fyrir einelti. Á undan henni kemur spurning um hvort svarandi hafi orðið fyrir einelti. Seinni spurningin birtist aðeins ef peirri fyrri er svarað játandi.

Brottfall: Svarandi telst hafa fallið á brott úr könnuninni á peim stað par sem hann er með gagnagat ef hann er með gagnagöt á öllum spurningum sem koma á eftir.

v: Spurning par sem aðeins er hægt að velja einn svarmöguleika.

Fjölkostaspurning: Spurning par sem hægt er að velja fleiri en einn svarmöguleika. Slíkar spurningar voru taldar sem einn spurningaliður og litið var svo á að spurningu hefði verið svarað ef svarandi hakaði við einn eða fleiri. Á Mynd 1 má sjá dæmigerða fjölkostaspurningu.

\section{Fjölskyldan}

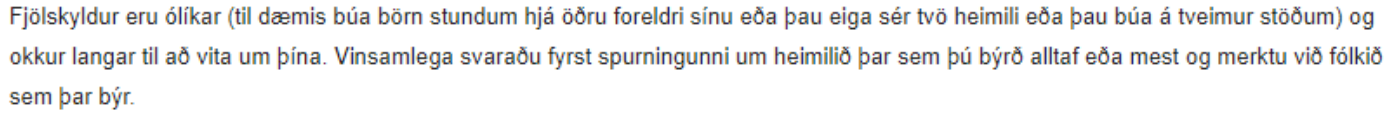

Mynd 1. Dæmigerð fjölkostaspurning. Spurning tekin úr HBSC.

Gagnagat: Рað er talið gagnagat ef ekkert svar er í breytu sem ætti að innihalda svar.

Opin spurning: Allar spurningar par sem svarandi slær inn texta eða tölur frekar en að haka við svarkosti (eða, í örfáum tilfellum, hreyfa sleða) teljast opnar spurningar.

Sati spurningar: Spurningaliðum var raðað frá peim sem birtist svaranda fyrst til pess sem birtist síðast og taldist staðurinn í röðinni vera sæti spurningar. Pegar birtingarskilyrði eru á spurningum segir sæti spurningar ekki til um hversu margar spurningar svarandi hafði séð áður en hann kom að viðkomandi spurningu en ef einhverjar tvær spurningar hafa birst svaranda pá hefur sú sem er í lægra sæti alltaf birst svarandanum á undan peirri sem er í hærra sæti. Sæti spurningar segir mun betur til um hversu margar spurningar svarandi hafði séð áður í ESPAD en HBSC vegna pess hversu miklu minna er um birtingarskilyrði í ESPAD-könnuninni. Í PISA-könnuninni er aðeins ein spurning með birtingarskilyrði og pví segir sæti spurningar mjög vel um hversu margar spurningar höfðu áður birst svaranda í peirri könnun.

Spurningaliður: Hér var spurningaliður talinn í hvert skipti sem svarandi parf að gefa svar. Spurningarnar í spurningatöflunni á Mynd 2 teljast til dæmis sem fjórir spurningaliðir par sem svarandi parf að svara fjórum sinnum. Undantekning frá peirri reglu að telja spurningalið fyrir hvert tilfelli par sem svarandi parf að gefa svar er gerð pegar spurningar eru fjölkosta. Allir möguleikar eru pá taldir saman sem einn spurningaliður. 
Spurningatafla: Röð spurninga með eins svarmöguleika, ýmist einkosta, fjölkosta eða opinna, sem settar eru upp í töflu par sem spurningar eru í röðum en svarmöguleikar í dálkum með sameiginlegum spurningastofni eða fyrirsögn. Spurningar eru hér taldar í sömu spurningatöflu ef pessi skilyrði eru uppfyllt pótt spurningar birtist ekki allar á einum skjá. Á Mynd 2 má sjá dæmigerða einkosta spurningatöflu.

\section{Hversu oft gerist eftirfarandi i íslenskutímunum bínum?}

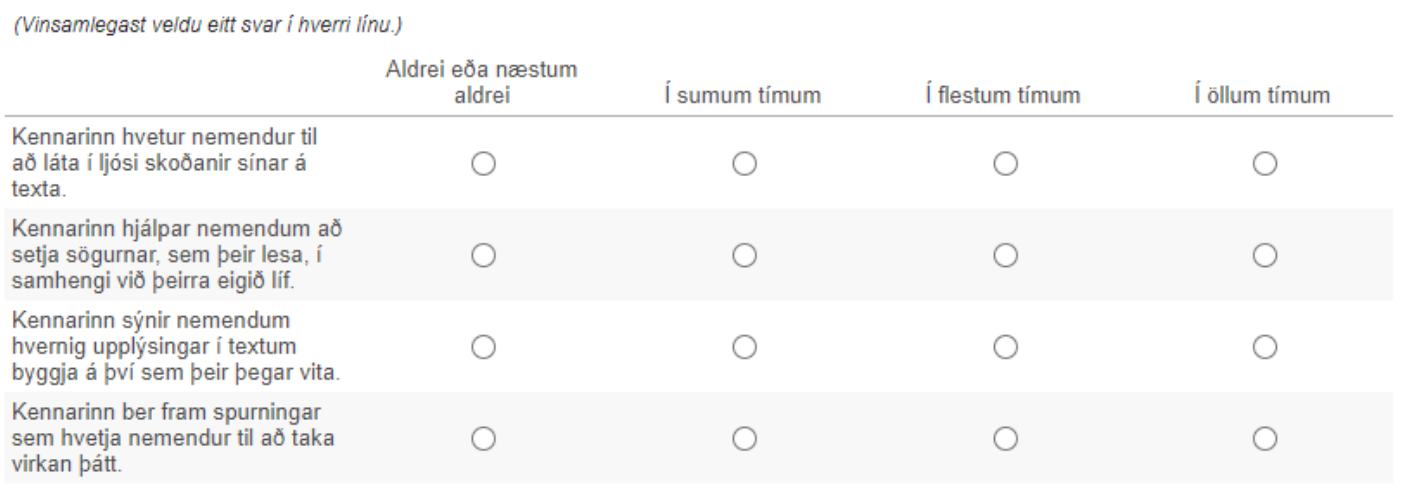

Mynd 2. Dæmigerð spurningatafla. Spurningar teknar úr PISA-spurningalista. Athugið að spurningataflan hefur verið sett upp í dæmigerðu kannanaforriti en útlit hefur að öllum líkindum verið ögn frábrugðið í fyrirlögn.

\section{Niðurstöður og umræður}

\section{ESPAD}

Hlutföll vöntunargilda í ESPAD fyrir alla svarendur og skipt eftir kyni má sjá á Mynd 3. Svarta línan með punktunum sýnir hlutfallið sem svarar ekki spurningunni í viðkomandi sæti (gagnagöt) en rauða línan sýnir hlutfallið sem svarar ekki spurningunni í viðkomandi sæti og engri spurningu eftir pað (brottfall). Pessir svarendur eru með öðrum orðum hættir pátttöku í könnuninni. Blái borðinn auðkennir kafla par sem spurningar eru með birtingarskilyrðum. Athugum að par sem birtingarskilyrði eru er svarhlutfall reiknað miðað við fjöldann sem á að svara spurningunni en ekki heildarfjölda svarenda og hlutfall vöntunargilda getur pví farið niður fyrir hlutfallið sem fallinn er á brott úr könnuninni á peim köflum. Myndin er í hárri upplausn og polir vel ef pysjað er inn. 

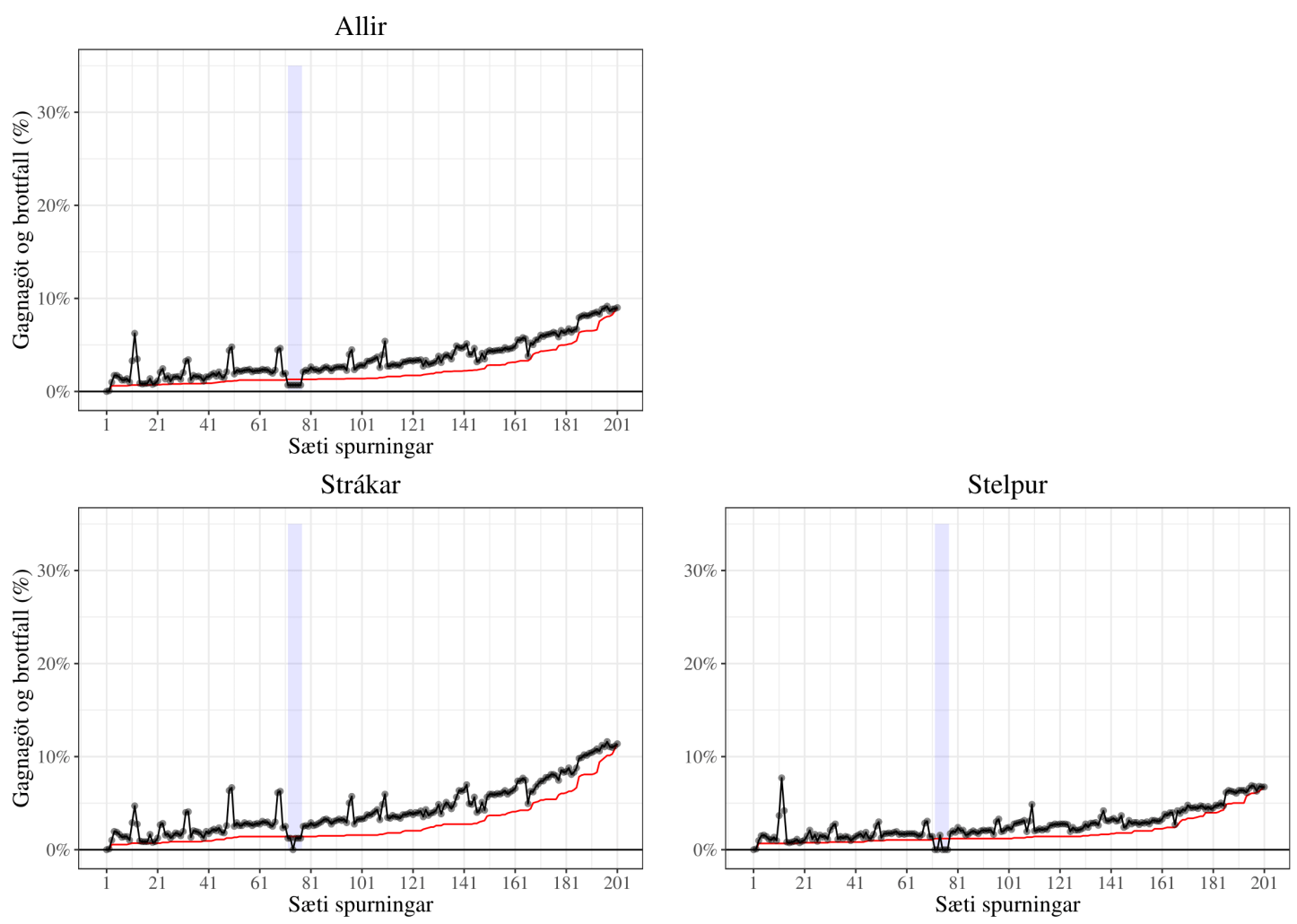

Mynd 3. Hlutföll gagnagata í ESPAD samtals og eftir kyni. Svarta línan segir til um hlutfall svara sem vantar við tiltekinni spurningu og rauða línan segir til um hlutfall sem er hætt að svara könnuninni. Blái borðinn gefur til kynna að spurningar séu með birtingarskilyrðum.

Á Mynd 3 sést nokkur munur á hegðun kynjanna. Strákar sleppa fleiri spurningum en stelpur. Peir eru bæði líklegri til að detta út úr könnuninni (rauða línan hækkar hraðar) og til að sleppa einstökum spurningum (svarta línan liggur hærra). Strákar eru einnig líklegri en stelpur til að hoppa yfir spurningar án pess að hætta pátttöku í könnun (meira bil á milli rauðu og svörtu línunnar).

Við sjáum nokkuð af áhugaverðum toppum á línunni. Fyrsti (sæti 11-13) er í spurningum um fjarvistir og skróp og kunnum við engar skýringar á hvers vegna svarendur eru tregari til að svara um pað en annað. Næstu á eftir (til dæmis sæti 22-23, sæti 31-33 og sæti 48-50) eru spurningar par sem svarendur eru spurðir um rafrettunotkun um ævina og daglega, áfengisneyslu og ölvun um ævina, síðastliðna 12 mánuði og síðastliðna 30 daga og svo framvegis. Рað virðist sem töluverðum hópi svarenda pyki nóg að svara einum lið en athyglisvert er að gagnagötin eru hlutfallslega fátíðust hjá peim sem segjast aldrei um ævina hafa gert pað sem spurt er um.

Í seinni hluta könnunar eykst brottfallið hratt og endar yfir 11\% hjá strákum og í tæpum 7\% hjá stelpum (um 9\% yfir heildina). Vaknar pá spurningin hvort petta sé pýðingarmikið brottfall? Par sem pað er vel pekkt að vímuefnaneysla er tengd röskunum á borð við athyglisbrest og mögulega lestrarörðugleikum (Lee o.fl., 2011; Yates, 2013) er pað alls ekki ósennilegt. Til að svara pessu var brottfall skoðað eftir svörum á tveimur spurningum sem birtast snemma í könnuninni og eru líklegar til að vera tengdar peirri áhættuhegðun sem ESPAD er ætlað að meta meðal unglinga.

Á Mynd 4 er brottfall sýnt með sama hætti og á Mynd 3 nema að svarendum er skipt eftir pví hvernig peir svara spurningu um skróp síðustu 30 daga. Staðsetning spurningar sem skipt er eftir er merkt með lóðréttri línu. Athugið að greiningin nær ekki til svarenda sem svöruðu henni ekki. Par sést að svarendur sem hafa skrópað eru mun líklegri bæði til að heltast úr lestinni og sleppa einstökum spurningum. Pessi tilhneiging ágerist eftir pví sem líður á könnunina. 


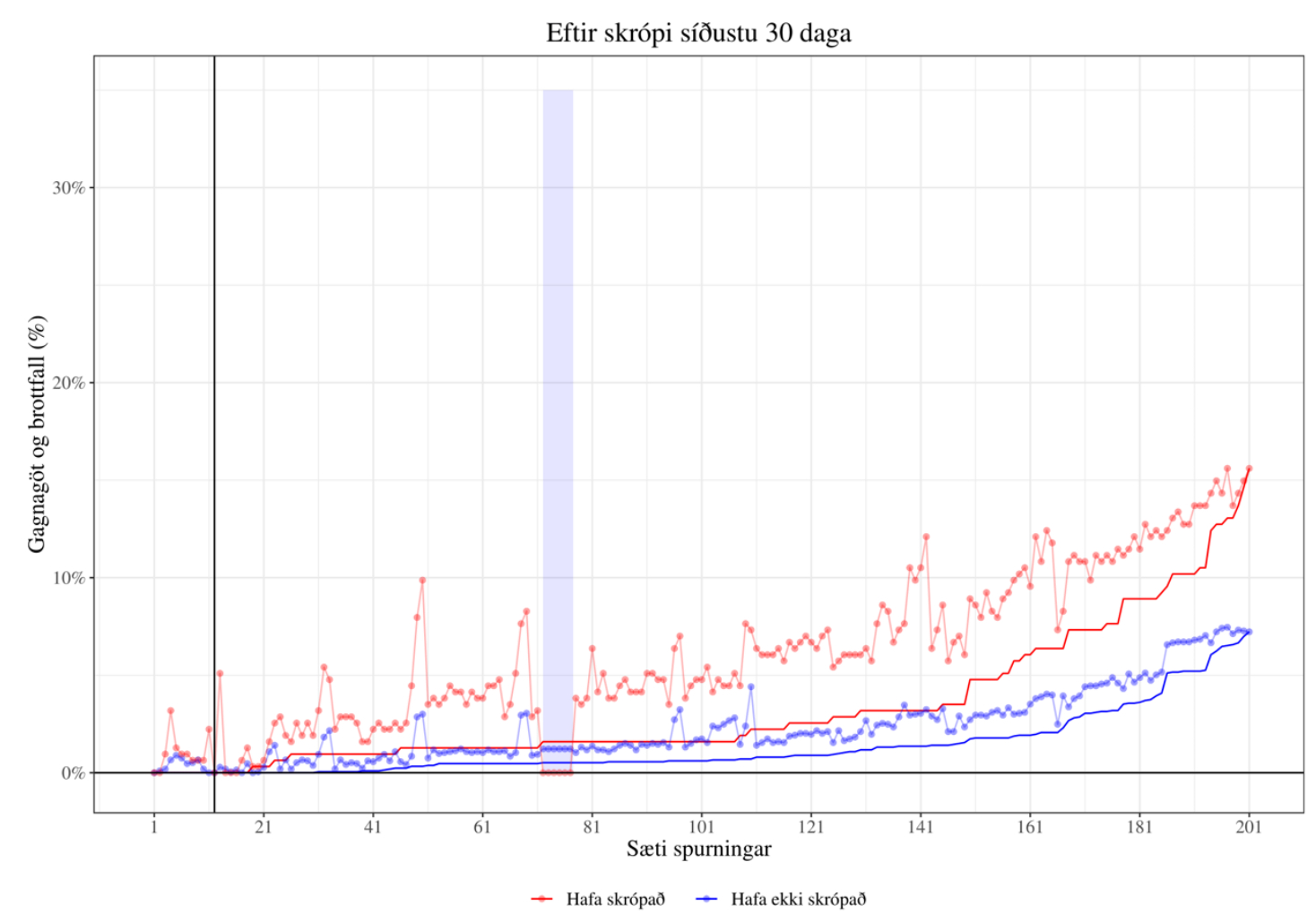

Mynd 4. Brottfall eftir svari við spurningu um skróp undanfarna 30 daga. Staðsetning spurningar sem skipt er eftir er merkt með lóðréttri línu. Ljósu línurnar með punktunum sýna hlutfall gagnagata á einstökum spurningum. Pær dekkri sýna hlutfall svarenda sem eru fallnir á brott úr könnun. Blálitaði borðinn gefur til kynna kafla par sem spurningar eru háðar birtingarskilyrðum.

Раð sama kemur í ljós ef svarendum er skipt eftir spurningu um hvort peir hafa reykt. Svör sem eru merki um áhættuhegðun eru með skýrum hætti tengd við aukna áhættu á brottfalli úr könnun, samanber Mynd 5. 


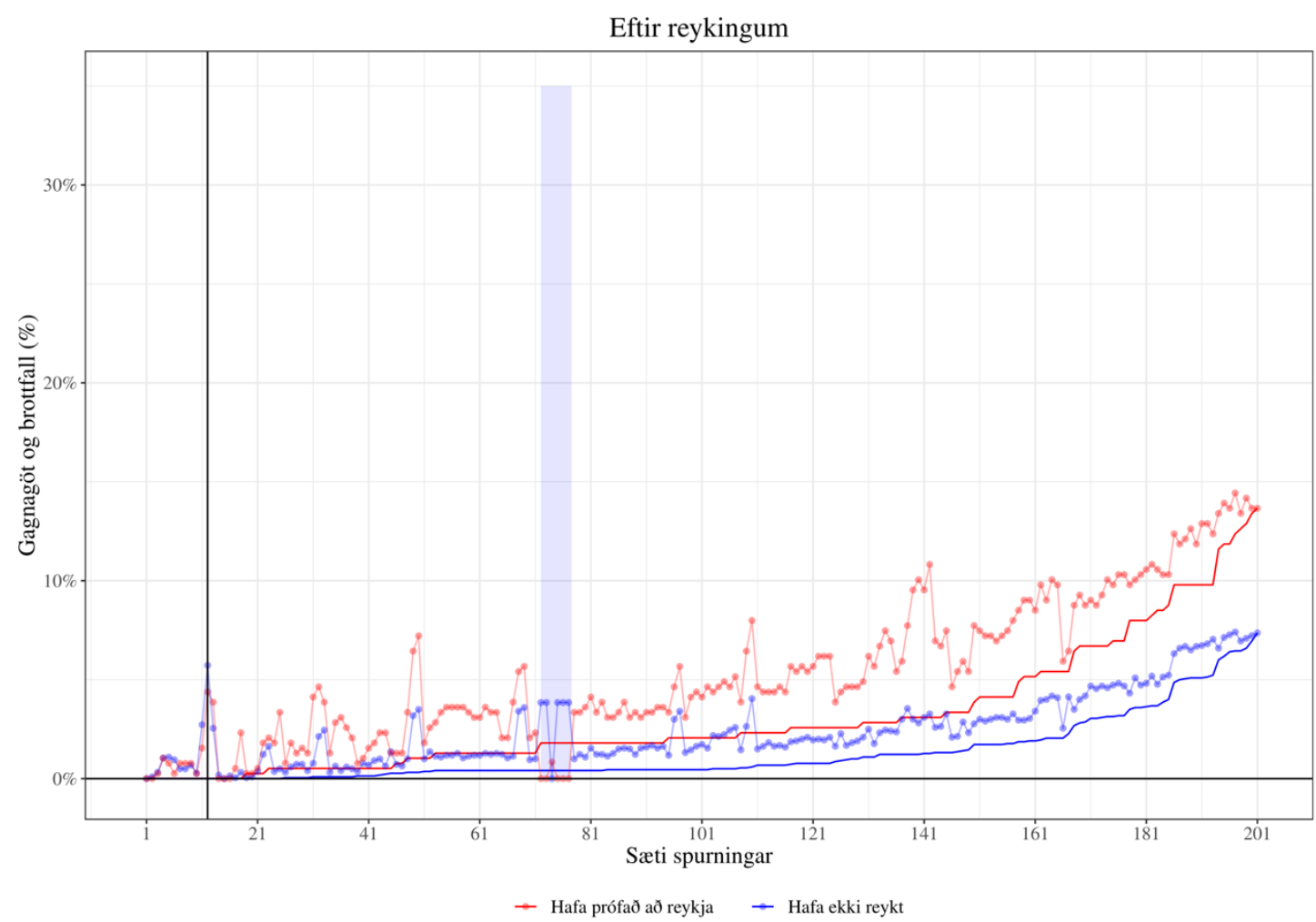

Mynd 5. Brottfall eftir svari við spurningu um reykingar. Staðsetning spurningar sem skipt er eftir er merkt með lóðréttri línu. Ljósu línurnar með punktunum sýna hlutfall gagnagata á einstökum spurningum. Pær dekkri sýna hlutfall svarenda sem eru dottnir út úr könnun. Blálitaði borðinn gefur til kynna kafla par sem spurningar eru háðar birtingarskilyrðum.

Lesendur kunna að hafa tekið eftir tröppum í línunni sem sýnir brottfall. Pær eiga sínar skýringar eins og sjá má á Mynd 6 par sem upphaf og endir spurningataflanna eru sýnd með bláum og gulum borðum til skiptis. Við sjáum að svarendur hafa nokkra tilhneigingu til að gefast frekar upp við upphaf nýrrar spurningatöflu en í miðri töflu og pegar svarendur taka að heltast úr lestinni að verulegu ráði undir lokin - margir sennilega að brenna inni á tíma - koma tröppurnar berlega í ljós. 


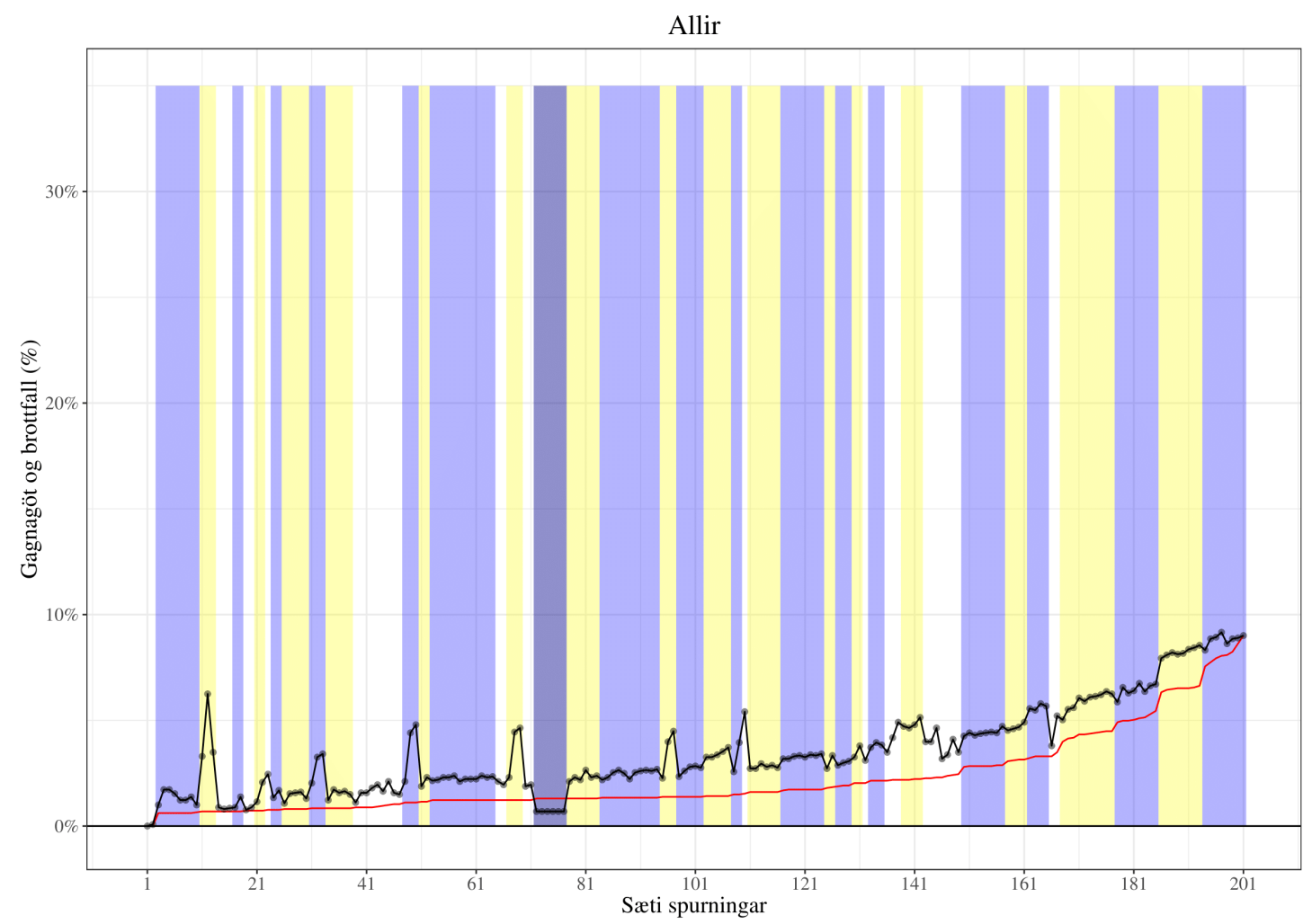

Mynd 6. Brottfall sýnt eins og á Mynd 1. Upphaf og endir spurningablokka eru merkt með bláum og gulum borðum til skiptis.

Hér hlýtur sú spurning að vakna hvort spurningatöflur sem slíkar stuðli að brottfalli enda virðast gagnagöt heldur færri par sem spurningar eru stakar. Fyrri rannsóknir hafa bent til að fullorðnir svarendur taki síður pátt í spurningakönnun með spurningatöflum (Chesnut, 2008) og pær skili gjarnan verri gögnum (Mavletova o.fl., 2018; Roßmann o.fl., 2018) pótt áhrifin séu, eðlilega, töluvert breytileg eftir efni og markhópi könnunar (Revilla, 2017). Fyrirfram er pað ekki ósennilegt að spurningaform sem gjarnan pvælist fyrir fullorðnum svarendum geti stuðlað að gagnagötum og brottfalli í könnunum meðal unglinga. Hins vegar er pað líka svo að pað verða alltaf skjáskipti (ný „blaðsíða”) pegar farið er á milli spurninga eða spurningataflna í ESPAD og pví gæti verið um að ræða áhrif skjáskipta.

\section{HBSC}

HBSC er nokkuð frábrugðin ESPAD. Hún er lögð fyrir breiðari aldurshóp, er um fjölbreyttara efni og inniheldur fjölbreyttari og jafnari blöndu af spurningategundum. Gögnin úr HBSC er meðal annars áhugavert að skoða með tilliti til peirra áhrifa sem spurningatöflur geta haft á brottfall.

Á Mynd 7 má sjá hlutfall vöntunargilda hjá öllum karlkyns og kvenkyns svarendum í öllum bekkjum í HBSC. Kaflar par sem spurningar eru í löngum spurningatöflum (3 spurningar eða meira) eru einkenndir með rauðum borðum ${ }^{1}$. Kaflar par sem birtingarskilyrði eru til staðar eru merktir með bláum borðum (ef spurningatafla er með birtingarskilyrðum verður borðinn pví vínrauður á peim kafla). pað er rétt að hafa í huga að par sem sumar spurningar birtast aðeins ákveðnum aldurshópum getur fjöldi svarenda á bak við tölurnar verið nokkuð ólíkur eftir pví hvar í listanum spurning er.

Rétt er að taka fram að vegna mistaka við fyrirlögn voru birtingarskilyrði sett pannig upp að spurningar 76 og 78 birtust peim sem ekki svöruðu skilyrðisspurningunum og reiknast hlutfall gagnagata par gríðarlega hátt, en peim er sleppt á Mynd 7. Pað er ekki með góðu móti hægt að sýna hlutfall svarenda sem hættir eru að svara á myndinni par sem birting nokkurra spurninga er háð bekk. Brottfallið

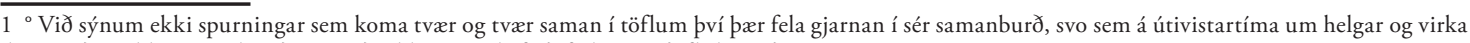
daga. Pað er ekki ósennileg að pær auðveldi svarverkefnið frekar en að flækja pað. 
er í staðinn sýnt á Mynd 8. Spurningar í sætum 61 og 62 eru opnar spurningar par sem beðið var um hæð og pyngd svarenda en peir gátu slegið hvað sem er inn. Töluvert var um svör á borð við „Kemur pér ekki við“ eða „9000!“. Par sem talning gagnagata fyrir pær spurningar kalla á handflokkun svara í raunhæf svör og útúrsnúning er peim spurningum sleppt í greiningunni.

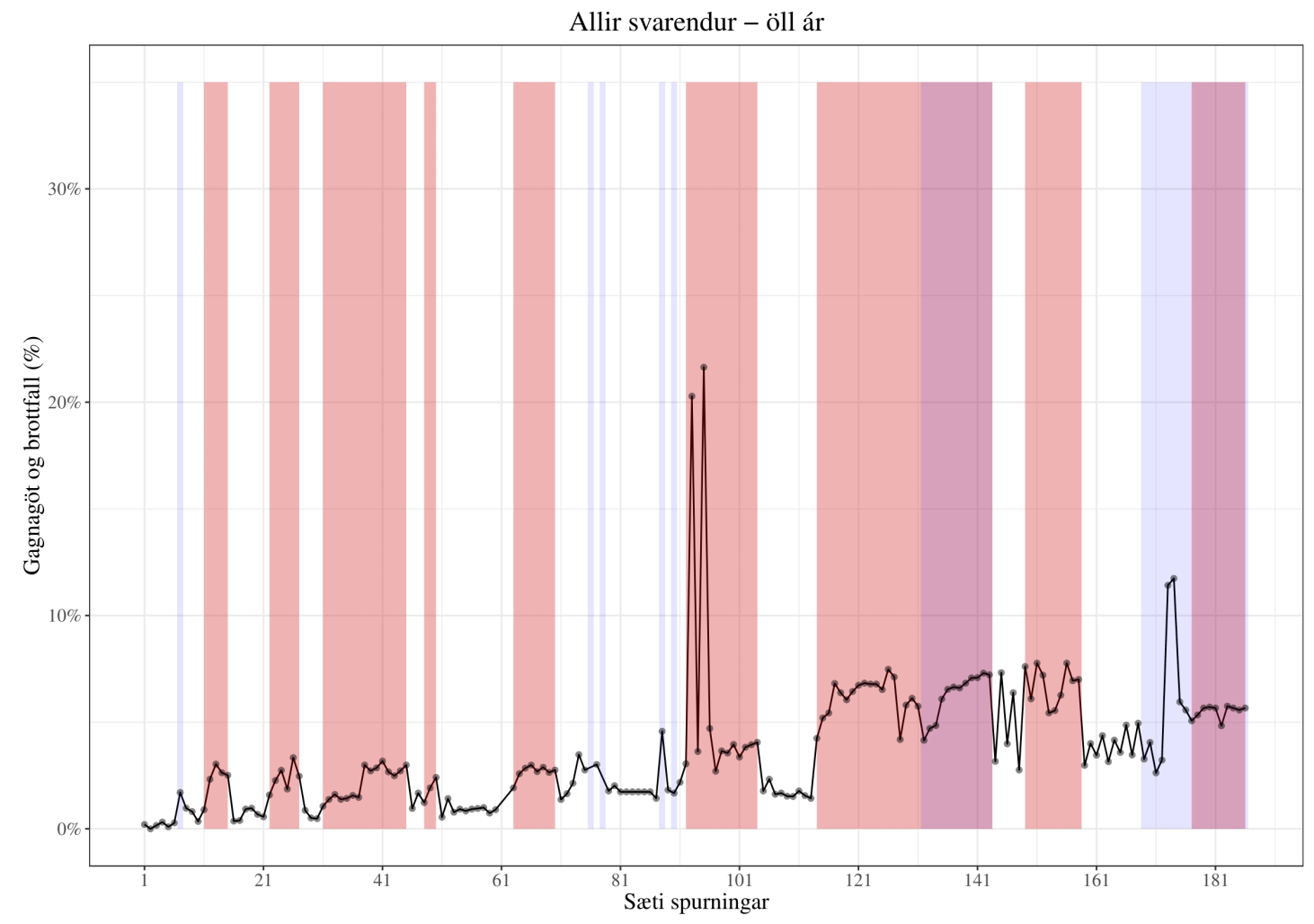

Mynd 7. Hlutfall vöntunargilda á spurningum á HBSC-spurningalistanum í heild. Bil par sem spurningar eru í blokkum (með premur eða fleiri spurningum) eru auðkennd með rauðum borða. Bil par sem spurningar eru háðar birtingarskilyrðum eru auðkennd með bláum borða. Bil par sem spurningar eru bæði í töflum og með birtingarskilyrðum verða vínrauð.

Hér sjáum við nokkur merki um að gagnagöt séu gjarnan fleiri par sem spurningar eru í töflum heldur en par sem pær standa stakar. Tveir áberandi toppar eru við sæti 93 og 95. Petta eru spurningar um samskipti við stjúpforeldra. Ekki er ósennilegt að margir svarendur sem ekki eiga slíka sleppi peim spurningum . Petta er merkilegt í ljósi pess að boðið er upp á svarmöguleikann „Â ekki eða hitti ekki viðkomandi“" við pessum spurningum en hann virðist ekki notaður. Til að átta okkur betur á mögulegum áhrifum spurningablokka teiknum við upp gagnagöt eftir kyni og bekk á Mynd 8. Athugið að myndin er í hárri upplausn og polir vel að pysjað sé inn. 

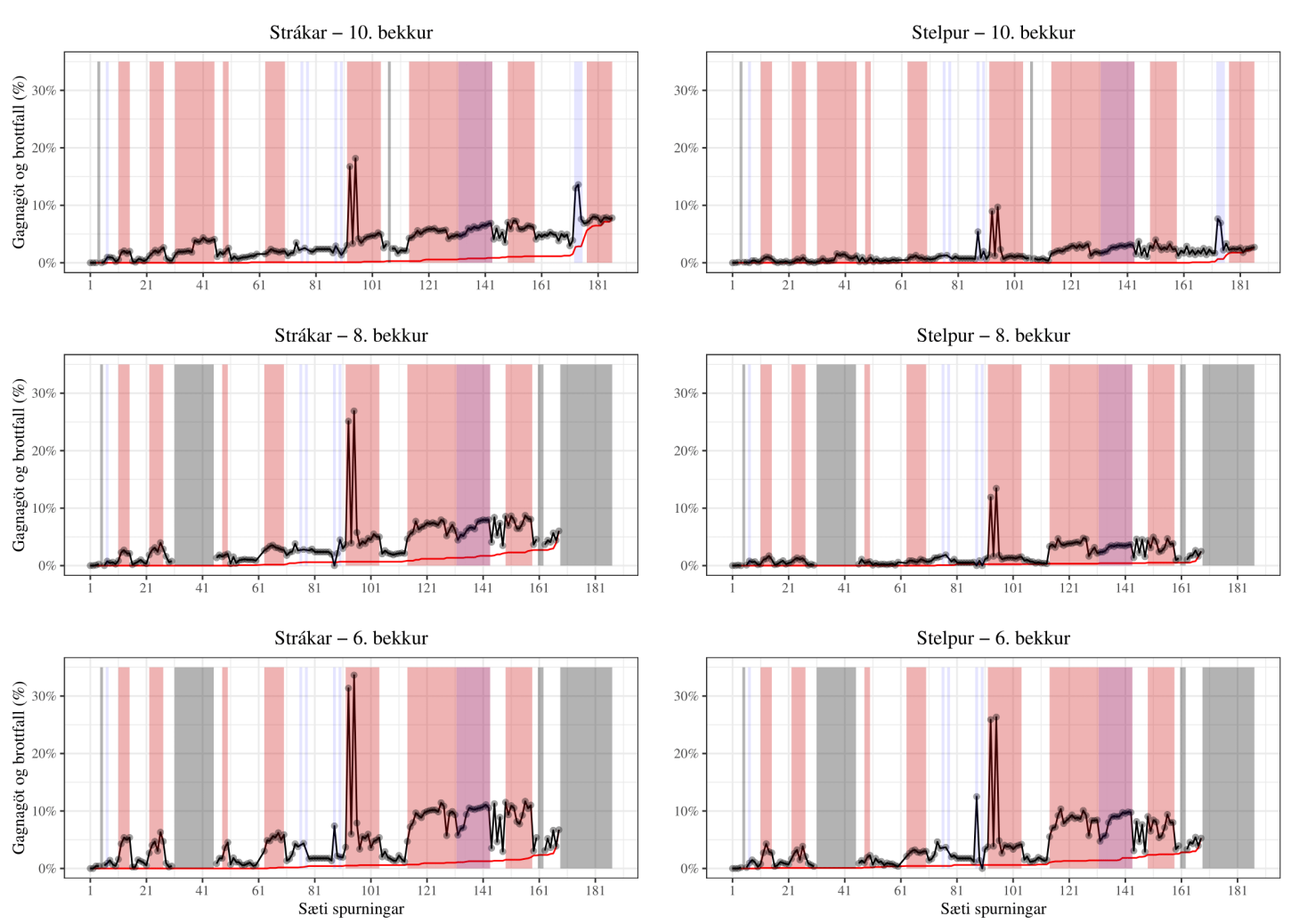

Mynd 8. Hlutfall vöntunargilda eftir bekk og kyni. Vöntunargildi og brottfall eru sýnd eins og á Mynd 3. Spurningatöflur með premur eða fleiri spurningum eru merktar með rauðum borða. Bil par sem spurningar eru háðar birtingarskilyrðum eru sýnd með bláum borða með peirri undantekningu að spurningar sem ekki eru sýndar í bekk eru merktar með gráu. Svarta línan sýnir heildarhlutfall gagnagata á hverri spurningu og rauða línan hlutfall svarenda sem eru fallnir á brott úr könnuninni.

Við sjáum ekki mikinn kynjamun í 6. bekk en nokkuð skýr merki um að spurningatöflur dragi úr svörun hjá svarendum. Í 8. og 10. bekk sést kunnuglegt mynstur par sem biliðá milli rauðu og svörtu línunnar er breiðara hjá drengjum en stúlkum sem pýðir að peir hoppa frekar yfir einstök atriði. Spurningatöflur eru minna vandamál fyrir eldri svarendur en yngri og pá sérstaklega eldri stelpur en vöntunargildi eru pó að jafnaði fleiri í spurningatöflum en stökum spurningum. Rauða línan (sem sýnir brottfallshlutfall) fer seinna af stað. Hún kemst ekki jafn hátt og hún er í sama raðsæti hjá stúlkum í ESPAD pótt hún taki stórt stökk á lokasprettinum hjá strákum í 10. bekk (við 10 spurninga töflu um kynjahlutverk). Mögulega stafar petta af pví að HBSC er um margbreytilegra efni og spurningar í fjölbreyttari framsetningu. Ef svaranda leiðist eða á erfitt með að skilja spurningar pá getur hann frekar sleppt úr og fundið spurningar sem honum líkar betur eða eru auðveldari.

\section{PISA}

Aðstandendur PISA eru mikið bjartsýnisfólk um áhuga svarenda. Spurningalistinn peirra er ekki einungis lagður fyrir eftir tvær klukkustundarlangar lotur af prófverkefnum sem svarendur fá enga endurgjöf fyrir heldur er hann 307 spurningaliðir á lengd.

Á Mynd 9 má sjá svörun íslenskra unglinga við könnuninni teiknaða upp með sama hætti og á $M y n d$ 3. Eins og aðrar myndir eru hún í hárri upplausn og polir vel að pysjað sé inn. Topparnir fremst eru spurningar um menntun foreldra en pær virðist vefjast nokkuð fyrir íslensku nemendunum eins og í flestum pátttökulöndunum. Í Suður-Kóreu, par sem hlutfall gagnagata flöktir annars í kring um 1\%, eru t.d. mörg gagnagöt á pessum spurningum. Kúfurinn á sætum 138-154 eru spurningatöflur sem koma með löngum formála. Nokkuð stór hópur svarenda sleppir peim einfaldlega. 
Að mörgu leyti svipar mynstrinu til pess sem við sjáum í ESPAD. Við sjáum meira bil á milli brottfallslínu og línu fyrir heildarfjölda gagnagata hjá strákum sem segir okkur að peir sleppa frekar einstökum spurningum. Framan af rís brottfallslínan líka hraðar hjá strákum en stelpum. Staðan breytist pó nokkuð undir lokin pegar brottfallslínan tekur að hækka hraðar hjá stelpum og endar leið sína örlítið ofar en hjá strákum. Trúlegasta skýringin á pessu er að par sem stelpur virðast frekar reyna að svara öllum atriðum séu pær líklegri til að brenna inni á tíma. Greining á gagnagötum eftir kyni hlýtur raunar að vekja einhverjar spurningar um að hvaða marki kynjamunur í frammistöðu á prófhlutanum er munur á nennu frekar en getu.

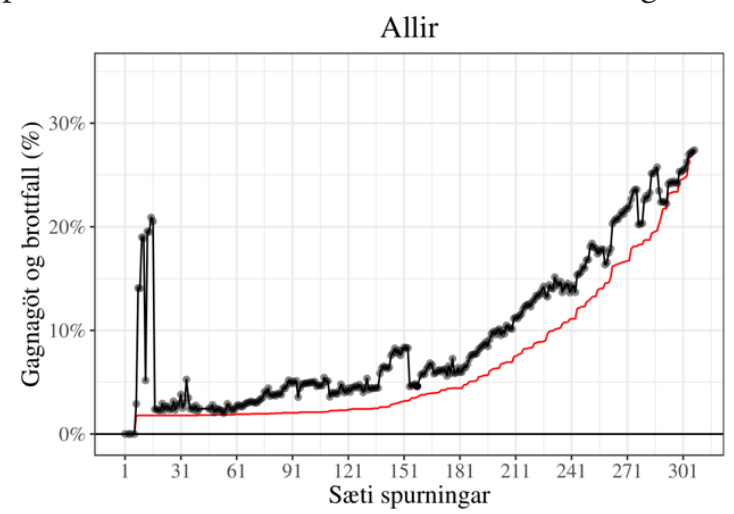

Strákar
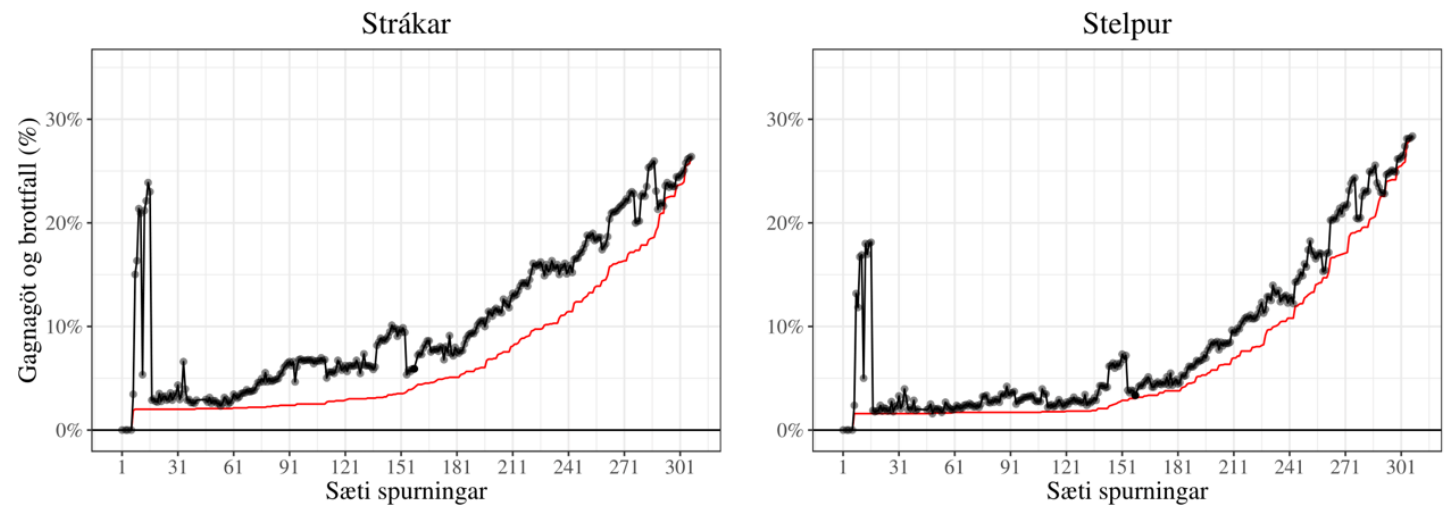

Mynd 9. Hlutfall gagnagata í PISA samtals og eftir kyni. Svarta línan segir til um hlutfall svara sem vantar við tiltekinni spurningu og rauða línan segir til um hlutfall sem er hætt að svara könnuninni. Ein spurning er með birtingarskilyrðum en er ekki merkt sérstaklega par sem borðinn myndi varla sjást.

Á Mynd 10 má greina tröppumynstur svipað pví sem sést í ESPAD. Upphaf og endir spurningataflna er merkt inn með borðum eins og á Mynd 6. Sérstök spurningatafla par sem svarendur purfa að slá inn vikulegan fjölda kennslustunda í mismunandi fögum er merkt með rauðu. Við sjáum að prep (snöggar hækkanir) í brottfallslínu eru ekki bundin við spurningatöfluskipti. Pau sjást stundum inni í lengri spurningatöflum. Petta kann að tengjast pví að spurningatöflur í PISA skiptast gjarnan á marga skjái. Prep koma pó alls ekki alltaf fram við skjáskipti (skjáskipti er ekki með góðu móti hægt að merkja inn á myndina samhliða spurningatöflum). 


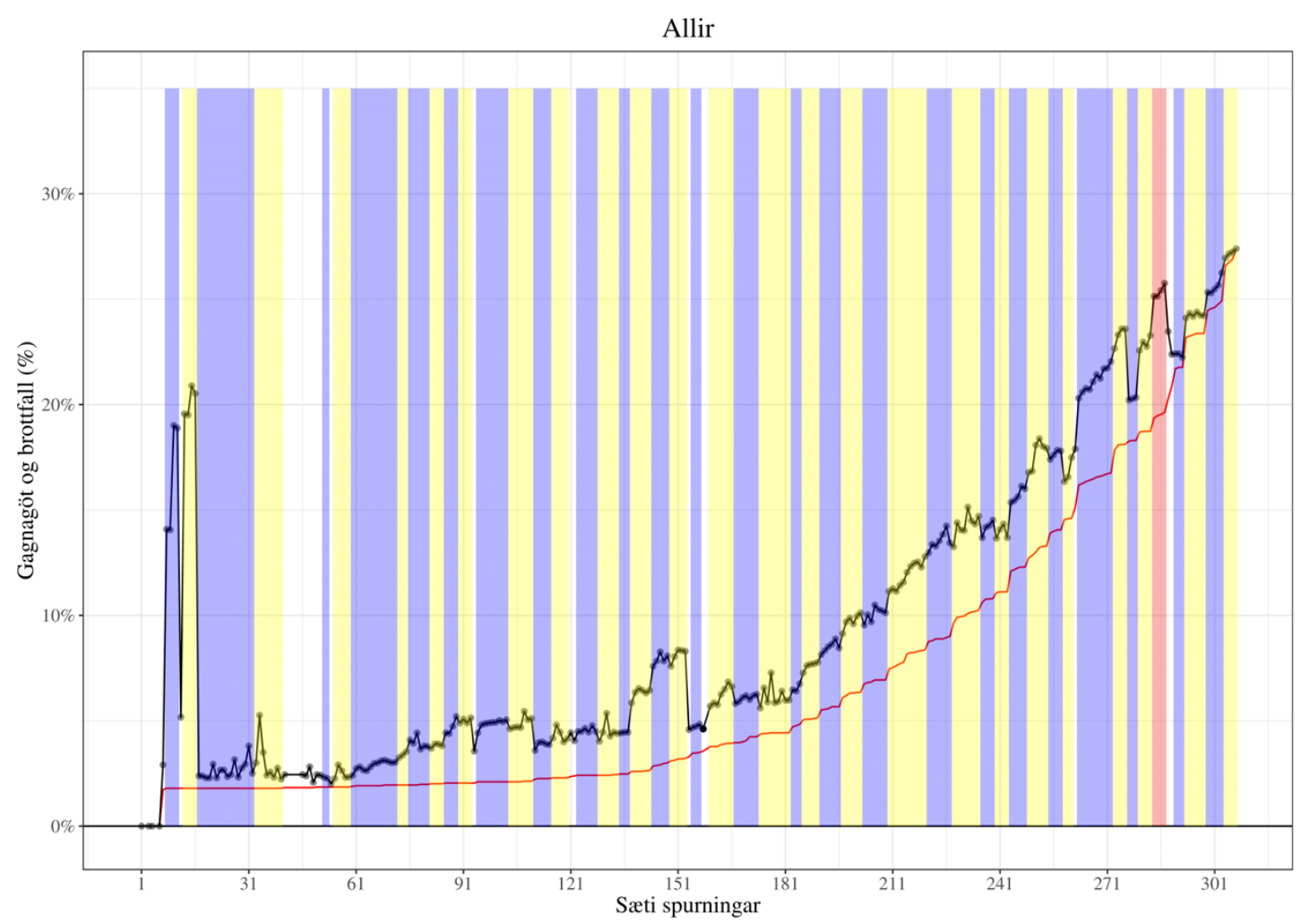

Mynd 10. Brottfall sýnt eins og á Mynd 3. Upphaf og endir spurningablokka eru merkt með bláum og gulum borðum til skiptis. Rauði borðinn sýnir spurningatöflu par sem svarendur purfa að skrifa inn tölur.

Annað athyglisvert við brottfallið í PISA er að brottfallslínan fer nokkuð hátt strax eftir allra fyrstu spurningarnar sem fyllt er upp í með skráargögnum. Í raun byrjar hún í um pað bil premur prósentum. Hluti úrtaksins svarar í raun engum spurningum á listanum.

\section{Samanburður á brottfalli og gagnagötum}

Á Mynd 11 sjáum við brottfall meðal svarenda í 10. bekk af báðum kynjum í HBSC borið saman við ESPAD og PISA. Við sjáum að brottfallslínan Í HBSC liggur töluvert fyrir neðan brottfallslínuna í hinum tveimur könnununum. Eins og má ráða af Mynd 8 skýrist stökkið undir lokin í HBSC af brottfalli stráka við síðustu spurningatöfluna. 


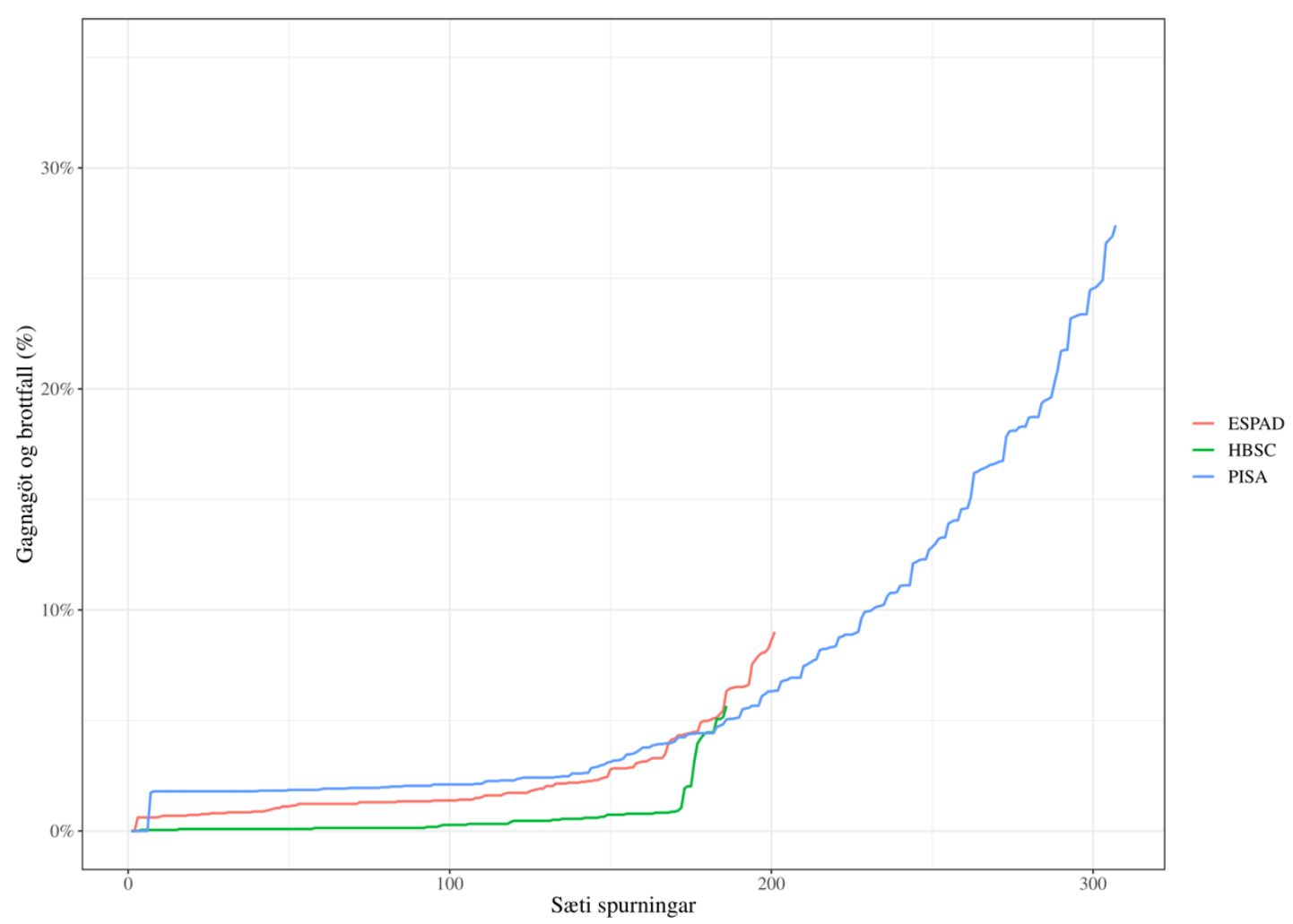

Mynd 11. Brottfall í ESPAD, HBSC og PISA eftir sæti spurningar.

Ein skýring á lægra brottfalli í HBSC gæti verið að svarendur par sleppi frekar stökum spurningum pannig að gagnagöt endi á að vera öðruvísi samsett en ekki færri. Samanburður á gagnagötum er pví sýndur á Mynd 12. Niðurstöðurnar par styðja ekki við pá skýringu. Myndin bendir frekar til pess að fjölbreytt efni og/eða spurningaform dragi úr líkunum á að svarandi falli alveg út úr könnuninni án pess að auka við heildarfjölda gagnagata. 


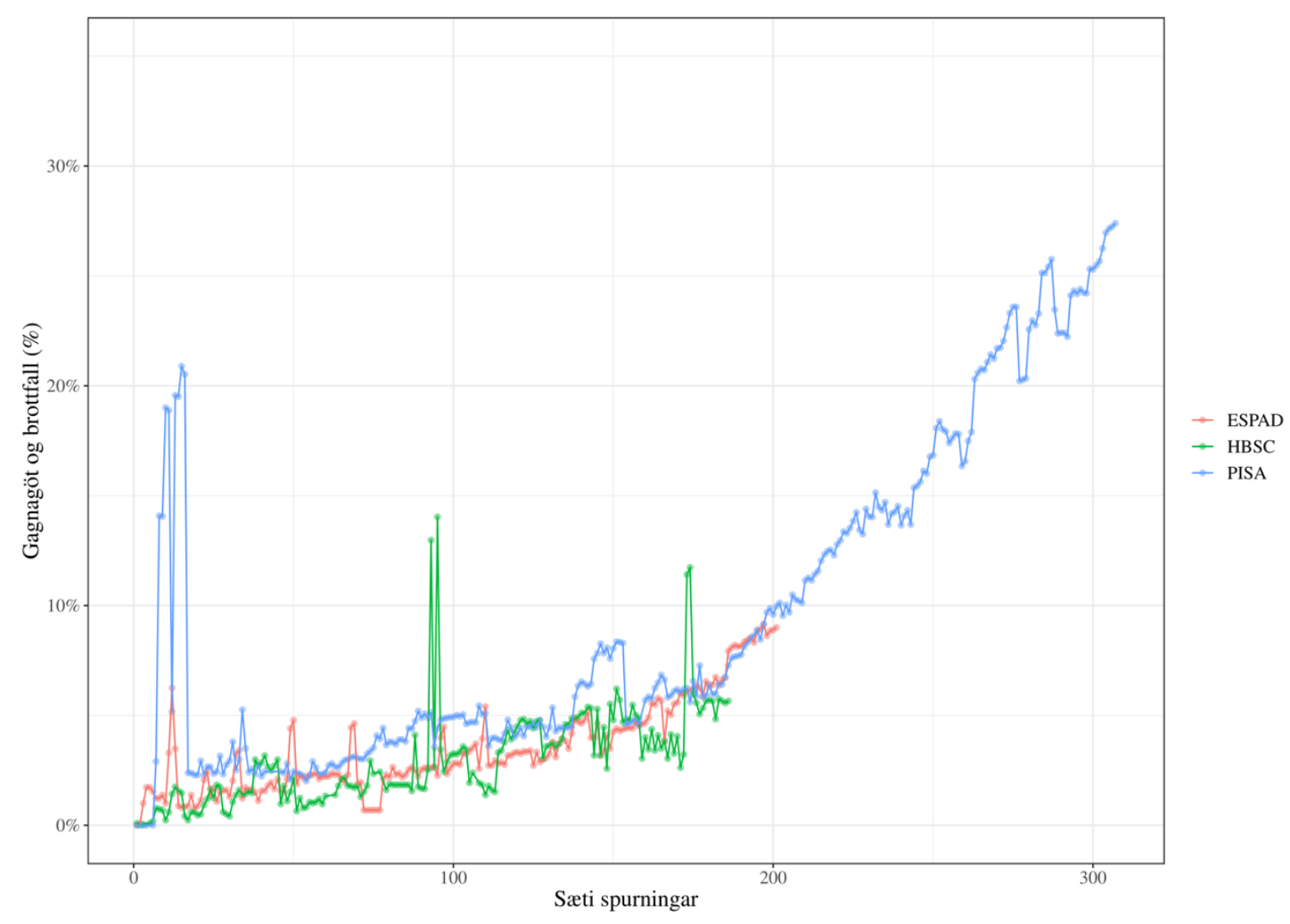

Mynd 12. Samanburður á gagnagötum í ESPAD, HBSC og PISA eftir sæti spurningar.

\section{Samantekt}

Við höfum hér skoðað mynstur gagnagata og brottfalls úr premur fjölpjóðlegum spurningakönnunum sem lagðar hafa verið fyrir unglinga á grunnskólaaldri á Íslandi. Sjá má mun eftir kyni í öllum premur könnununum og eftir aldri í HBSC en ósennilegt er að par sé um að ræða bein áhrif kyns og aldurs. Líklegra er að par komi fram áhrif persónueiginleika á borð við proska, hvatvísi, samviskusemi, lestrarörðugleika og svo framvegis sem aftur eru háðir kyni. Pað er ekki ósennilegt að pessir pættir hafi svo aftur tölfræðileg tengsl við hluti á borð við vímuefnanotkun, vanlíðan, andfélagslega hegðun og annað sem rannsakendur sem framkvæma kannanir á meðal unglinga hafa gjarnan áhuga á. Pað er að minnsta kosti ekki skynsamlegt að gefa sér að slíkt samband sé ekki til staðar - sem við erum í raun að gera ef við horfum framhjá gagnagötum. Við höfum raunar sýnt tvö dæmi úr ESPAD-rannsókninni par sem nokkuð skýr tengsl eru á milli áhættuhegðunar og brottfalls. Í pessu samhengi er rétt að hafa í huga að pótt peir sem ekki svara séu ekki stór hluti heildarsvarendahópsins getur brottfall samt sem áður leitt til meiriháttar bjaga ef spurt er um tiltölulega fátíða hegðun á borð við notkun fíkniefna.

Ef við gefum okkur að niðurstöður hér megi yfirfæra á aðrar spurningakannanir meðal unglinga getum við dregið af peim prjár lykilályktanir um heppilegt verklag við gerð spurningalista:

Í fyrsta lagi er rétt að forðast spurningar sem hafa ekkert upplýsingagildi. Í ESPAD sjáum við toppa í vöntunargildum par sem svarendur eru spurðir um hegðun sem peir svara í raun um í annarri spurningu. Parna verða að vísu ekki til gagnagöt sem erfitt er að fylla en pað er sóun á tíma og orku svarandans að láta hann lesa og taka afstöðu til spurningar sem hann svarar annars staðar.

Framangreint leiðir okkur að ályktun númer tvö en í henni felst að nauðsynlegt sé að hafa spurningalista af viðráðanlegri lengd. Ef við notum pað viðmið að brottfall haldist undir 5\% myndum við álykta að ESPAD-spurningalistinn sé heldur langur og PISA-spurningalistinn allt of langur. Minna er um að svarendur falli alveg út úr HBSC en pað er spurning hversu margir svarendur í peirri könnun hefðu brunnið inni á tíma hefðu peir aldrei sleppt að svara spurningum. 
Priðja ályktunin snýr að spurningatöflum. Við sjáum að sérstaklega yngri svarendur sleppa gjarnan spurningum í slíkum töflum (hvort sem pað er vegna pess að peim pykir pær erfiðar, leiðinlegar eða af öðrum ástæðum). Pótt minna verði vart við tilhneigingu til að sleppa spurningum í töflum meðal eldri svarenda er rétt að hafa í huga að peir sem á annað borð hoppa yfir pær hafa mögulega ekki náð jafnöldrum sínum í proska ef brottfallstilhneiging peirra líkist tilhneigingum yngri svarenda. Раð brottfall getur pví verið mjög kerfisbundið.

Rétt er að hafa í huga að ef fjöldi bókstafa er notaður sem mælikvarði á lengd spurningar eru töfluspurningar gjarnan mjög langar ef spurningastofn er talinn með. Áhrifin af töfluspurningum sem hér sjást gætu pví mögulega einungis verið áhrif af lengd. Hér reynum við pó ekki að greina áhrif lengdar í bókstöfum sérstaklega par sem lengd í bókstöfum er nokkuð háð staðsetningu og formi spurninga og pað er ekki augljóst hvort telja ætti með lengd spurningastofns í spurningatöflu. Slík greining kallar pví á gögn úr tilraunafyrirlögn par sem mismunandi samsetningar uppsetningar, staðsetningar og innihalds eru prófaðar.

Hér hefur ekkert verið rætt um gæði gagnanna sem spurningalistarnir skila. Pótt svarandi haki við svar parf hann ekki að hafa skilið spurninguna eins og spyrjandi meinti hana. Hann parf ekki einu sinni að hafa lesið hana. Ágæt dæmi um petta má finna í PISA-spurningalistanum. Meðal atriða par eru spurningar um ýmisleg gæði á heimilum svaranda, svo sem handbækur, orðabækur og „fræðsluhugbúnað“ (um 74\% svarenda segja að fræðsluhugbúnaður sé til á heimili peirra - hvað svo sem pað nú merkir). Við pennan lista eiga pátttökulönd svo að bæta premur spurningum sem eru sérstakar fyrir pað land, væntanlega vegna pess að almenn velsæld er nokkuð breytileg á milli pátttökulanda. Af einhverjum ástæðum urðu öryggiskerfi eða öryggisgæsla, „flatsjónvarp“ og gervihnattasjónvarp fyrir valinu á Íslandi í könnuninni 2018.

Mjög óformleg viðtalskönnun höfunda leiddi í ljós að pað er hreint ekki hægt að ganga að pví vísu að ungmenni á svipuðu reki og pau sem tóku pátt í könnuninni 2018 hafi sameiginlegan skilning á pví hvað gervihnattasjónvarp er. Samt svara 94\% svarenda spurningunni og um helmingur peirra svarar játandi. Hlutfallið sem svarar játandi er aðeins hærra í Reykjavík. Höfundar höfðu samband við söluaðila gervihnattamóttakara sem telja að fjöldi heimila á höfuðborgarsvæðinu með venjulegan gervihnattamóttakara hlaupi á fáum púsundum. Рað verður pví að teljast mjög líklegt að margir svarendur hafi giskað á merkingu spurningarinnar. Raunar eru mörg ný sjónvörp með innbyggðan búnað til að tengjast gervihnattadiski og vafalaust vita einhverjir svarendur af pessum búnaði og svara játandi pess vegna. Aðrir hafa kannski einfaldlega hakað við svarkost af handahófi. Pessi spurning er annars í sæti 31 og pað kemur kannski ekki sérstaklega á óvart að strákar eru um tvöfalt líklegri en stelpur til að sleppa henni.

Lexían hér er að spurningakönnun er annars konar samskiptamáti en samtal. Maður fær yfirleitt ekki skrýtin svör pótt spurning virki ekki eins og til er ætlast og svör merki ekki pað sem spyrjandi heldur. Raunar er svar engin trygging fyrir pví að spurningin hafi yfirhöfuð verið lesin. Við gætum ekki greint pað í könnununum sem hér eru skoðaðar pótt verulegur hluti svarenda hefði sleppt pví að lesa spurningarnar og alltaf hakað við til dæmis fyrsta svarkost eða síðasta. Af pví myndu yfirleitt ekki hljótast mótsagnakennd svör. $\mathrm{Pa}$ er gild spurning hvort einhver hluti svarenda sem leiddist pátttakan eða lentu í tímapröng hafi ekki brugðið á pað ráð.

Kannanirnar sem hér eru skoðaðar eru í sjálfu sér dæmigerðar fyrir alpjóðlegar kannanir meðal skólabarna að pví leyti að pær eru mjög langar. Sennilega skýrist petta að hluta til af pví að margir koma að framkvæmd peirra og auðveldara er að ná samkomulagi um að bæta við atriðum en að taka pau út. Að auki gæti orsökin verið oftrú rannsakenda á að skalagerð með tilheyrandi páttagreiningum og alfa-áreiðanleikastuðlum tryggi gæði gagna. Vafasömu spurningarnar úr PISA-könnuninni um efnisleg gæði á heimilum svarenda eru til dæmis sett í skala ásamt öðrum spurningum. Hann er síðan sameinaður tveimur öðrum skölum og telja menn sig pá vera komna með mælingu á félags- og efnahagslegri stöðu svarenda. Tölfræðilegar athuganir á „próffræðilegum eiginleikum“ (e. psychometric properties) skalanna eiga svo að tryggja gæði mælingarinnar. 
Maul (2017) gerði skemmtilegar tilraunir sem sýna vel hversu gagnslausar slíkar greiningar geta pó verið. Vel pekktur 8 atriða kvarði Carol Dweck (2006) „Theories of Intelligence“ var lagður fyrir fullorðna einstaklinga ásamt 8 atriða „Theories of Gavagai“ skalanum par sem lykilnafnorði í hverri spurningu var skipt út fyrir bullorðið „gavagai“ pannig að spurningin varð óskiljanleg. Upphaflegi skalinn reyndist hafa fyrirtaksgóða próffræðilega eiginleika (einvíð bygging, háar páttahleðslur, hár alfa-áreiðanleiki og fylgni við aðrar hugsmíðar). Vandinn er að „Theories of Gavagai“ reyndist ekki mikið verri. Sömu niðurstöður fengust með öðru bullorði („kanin“) og orði sem passar ekki inn í samhengið („quintessence“). Maul prófaði pá að leggja fyrir aðra kvarða sem samanstóðu af Lorem ipsum texta² og kvarða með tómum atriðum. Par varð útkoman ekki mikið sỉðri.

Parna gerðist ekkert dularfullt. Einvíð páttabygging pýðir í raun ekkert annað en að hvert atriði á listanum hefur álíka mikla fylgni við öll hin atriðin pegar tölugildi hafa verið hengd á svarmöguleikana með einhverjum hætti sem rannsakandi telur skynsamlegan. Pau pyrpast ekki saman í klasa. Alfa-áreiðanleiki er síðan aðeins mælikvarði á hlutfall samdreifni af heildardreifni og hækkar nokkuð hratt ef atriðum sem hafa að meðaltali jákvæða fylgni við atriðin sem fyrir eru er bætt við (svo lengi sem hún er ekki mjög lág). Vandinn við að treysta á slíkar greiningar er að fólk hefur svarstíla. Að öllu öðru jöfnu_erum við hrifnari af einni afstöðu til spurninga umfram aðrar. Sumir vilja helst vera sammála, aðrir helst ósammála. Enn aðrir vilja helst vera í miðjunni. Ef spurningarnar eru gerðar óskiljanlegar ráða svarstílar mestu um dreifingu svara, skýr páttabygging kemur fram og alfa-áreiðanleiki verður hár.

Tvær ástæður eru fyrir pví að við nefnum petta í samhengi við skólakannanir. Í fyrsta lagi er rétt að benda á að ef próun skala er að miklu leyti drifin áfram af próffræðigreiningum (pað er að segja, atriði valin eftir pví hvort pau hafi „góða próffræðilega eiginleika“) er alltaf hætta á að skiljanlegar spurningar séu sigtaðar út og eftir sitji óljósar og pvældar spurningar par sem svör eru frekar undir áhrifum svarstíla. İ öðru lagi nefnum við petta vegna pess að hefðbundnum aðferðum til skalagerðar er, eðli málsins samkvæmt, ekki hægt að beita á stök atriði. Pær vilja pví ýta undir fjölgun spurninga. Ef horft er á alfa-áreiðanleikastuðla við próun spurningalista ýtir pað enn frekar undir fjölgun atriða pví hann hækkar yfirleitt eftir pví sem atriðin eru fleiri. Pegar atriði eru orðin nógu mörg verður síðan illmögulegt að koma peim fyrir öðruvísi en í löngum spurningatöflum.

Spurningin um hvort langir spurningalistar með tilheyrandi páttagreiningum og alfa-útreikningum geti stundum verið gagnlegir liggur utan við efni pessarar greinar. Hér látum við staðar numið við að benda á að próffræðilegar greiningar veita alls enga tryggingu fyrir að rannsakandi fái góð gögn frá svaranda.

Ef óhjákvæmilegt er að hafa spurningalista mjög langa ættu rannsakendur ef til vill að íhuga aðferðir sem fela í sér úrtak spurninga. Ein leið er að skipta spurningunum í blokkir og leggja úrtak blokka fyrir hvern svaranda (Gonzalez og Eltinge, 2007). Pessi leið er raunar farin í prófhluta PISA-könnunarinnar. Ef pað er talið heppilegt er hægt að velja úr lykilspurningar og hafa pær í blokk sem lögð er fyrir alla svarendur. Önnur leið er að slembiraða spurningum eða blokkum af spurningum og er hún einföld í útfærslu í rafrænni fyrirlögn. Sú leið dregur ekki beinlínis úr kerfisbundnum gagnagötum vegna lengdar en hún gerir mun einfaldara að fylla upp í gagnagötin með viðeigandi tölfræðiaðferðum. Ef hvorug leiðin stendur til boða er hyggilegt að hafa spurningar um hluti á borð við vanlíðan, vímuefnanotkun og andfélagslega hegðun framarlega í könnunum ef ætlunin er að kanna pá hluti og pað er öruggara að láta lykilspurningar standa stakar frekar en í töflu.

Rétt er að hafa orð á að pau gagnagöt sem hér er rætt um eru vitaskuld ekki einu gagnagötin. Stór hluti gagnagata eru allsherjargagnagöt (engin svör frá svaranda) sem verða vegna fjarveru nemenda. Í ESPAD og HBSC er líka nokkuð um að skólar hafni pátttöku. Pá er mögulegt að einstakir nemendur eða forráðamenn peirra hafni pátttöku. Augljóslega geta verið tengsl á milli fjarvista og margra af peim páttum sem spurt er um í barna- og unglingakönnunum og vel má vera að skólar sem sampykkja pátttöku séu frábrugðnir peim sem hafna. Gagnagöt sem hljótast af pessum orsökum eru pví vitaskuld ekki síður ógn við réttmæti niðurstaðna. Séu upplýsingar um pýði eða úrtaksramma til staðar ættu rannsakendur vitaskuld að gera grein fyrir slíku allsherjarbrottfalli.

Lorem ipsum texti er merkingarlaus gervilatínutexti sem gjarnan er notaður til að prófa prentuppsetningar. 
Að lokum má benda á að áður en íslensk börn og unglingar hafa lokið grunnskólanámi eru pau flest búin að svara mörgum stórum spurningakönnunum, sumum oftar en einu sinni, auk tilfallandi kannana á vegum skólanna sjálfra og í tengslum við lokaverkefni háskólanema. Pví er nokkuð ljóst að svarbyrði pessa hóps er ekki léttvæg. Við hvetjum pví rannsakendur til að íhuga vel í hverju tilviki fyrir sig hvort fleiri spurningar með aukinni svarbyrði og aukinni hættu á kerfisbundnu brottfalli borgi sig pegar allt er saman reiknað.

\section{Item non response in surveys among adolescents in Iceland}

Several school-based surveys among Icelandic adolescents are conducted regularly. The topics of these surveys include mental and physical well-being, substance use, academic work, school environment, leisure and sports activities, media and internet use and family environment. Results from these surveys play a significant role in the making of educational and youth policies in Iceland.

The questionnaires used in these surveys are quite long and sometimes involve demanding response tasks. As a result, it is quite possible that item missing data might be missing systematically, leading to substantially biased findings, especially if statistical analyses that adjust for missingness are not used.

In the present study we look at the proportion of item missing data in three large surveys among Icelandic adolescents, European School Survey Project on Alcohol and Other Drugs (ESPAD), Health Behaviour in School-aged Children (HBSC), and the student questionnaire from the Programme for International Student Assessment (PISA). Analyses of the ESPAD data were restricted to respondents that reported their gender and we used the raw data as it appears before logical substitution and the removal of extreme respondents $(n=2609)$. Analyses of the HBSC data were restricted to respondents that reported their class and their gender as either male or female $(n=6946)$. Analyses of the PISA student questionnaire were restricted to those students who did not receive the simplified une heure test booklet $(\mathrm{n}=3230)$. Proportions of missing data were analysed graphically, both by item location and question format, using a novel type of diagnostic plots.

We examined two types of missing data. We looked at breakoff rates, where participants completely drop out of the survey and stop responding altogether. Secondly, we examined the item specific non response rates, where participants skip items but respond to items that appear later.

All three surveys had a substantial proportion of item missing data but this proportion varies greatly by item position, format and substance. The ESPAD questionnaire appears to be rather too long for the target population and the PISA student questionnaire is far too long. In HBSC there is a distinct association between question format and item missingness, especially among younger respondents. The other two surveys consist mostly of grids and single answer questions, resulting in insufficient question format variability to separate the effect of item format from that of location. For most of the duration of the survey the breakoff rate was substantially lower in HBSC than in the other two surveys. This could be because participants who dislike or have difficulty with question grids can skip over them and find other question formats that agree with them later on. However, there is also more variation in the substance of questions in HBSC and this could account for some or all of the difference. The overall rate of item missingness (due to both breakoff and item specific non response) is not much lower in HBSC than in the other surveys, once questionnaire length has been accounted for. 
Breakoff and item specific non response rates differ visibly across gender in all surveys and class in HBSC. Item specific non response is more common among boys in all surveys. Boys also have higher breakoff rates in HBSC and ESPAD but not in PISA, presumably because skipping more items made them less likely to run out of time. In the ESPAD data responses to questions on smoking and absenteeism (that appear early in the questionnaire) are clearly associated with both breakoff rates and item specific missing rates later in the questionnaire.

We conclude that item missing data in all surveys is far from being missing completely at random and has the potential to bias results substantially.

Finally, we discuss reasons for making questionnaires in surveys among adolescents as long as they are and whether this is truly necessary. We discuss options for reducing participants' response burden and/or mitigating the biasing effect of item missing data.

Key words: Item non response, HBSC, ESPAD, PISA

\section{Um höfunda}

Hans Haraldsson (haha@hi.is) er verkefnastjóri við Menntavísindastofnun Háskóla Íslands.

Ingibjörg Kjartansdóttir (ik@hi.is) er verkefnastjóri við Menntavísindastofnun Háskóla Íslands.

\section{About the authors}

Hans Haraldsson (haha@hi.is) is a project manager at the Educational Research Institute of the University of Iceland.

Ingibjörg Kjartansdóttir (ik@hi.is) is a project manager at the Educational Research Institute of the University of Iceland.

\section{Heimildir}

Chesnut, J. (2008). Effects of using a grid versus a sequential form on the ACS basic demographic data. Final report. US Census Bureau.

Dweck, C. (2006). Mindset: The new psychology of success. Philadelphia, PA: Psychology Press

ESPAD. (e.d.). Participating countries. http://www.espad.org/databases/participating-countries

Gonzalez, J. M. og Eltinge, J. L. (2007). Multiple matrix sampling: A review. Proceedings of the section on survey research methods (bls. 3069-3075). American Statistical Association.

Huntington-Klein, N., Arenas, A., Beam, E., Bertoni, M., Bloem, J., Burli, P. H., Chen, N., Greico, P., Ekpe, G., Pugatch, T., Saavedra, M. og Stopnitzky, Y. (2020). The influence of hidden researcher decisions in applied microeconomics. IZA Discussion Paper nr. 13233. Economic Inquiry, 59(3), 944-960. https://doi. org/10.1111/ecin.12992

Lee, S. S., Humphreys, K. L., Flory, K., Liu, R. og Glass, K. (2011). Prospective association of childhood attention-deficit/hyperactivity disorder (ADHD) and substance use and abuse/dependence: A meta-analytic review. Clinical Psychology Review, 31(3), 328-341. https://doi.org/10.1016\%2Fj.cpr.2011.01.006

Livingston, E. M., Siegel, L. S. og Ribary, U. (2018). Developmental dyslexia: Emotional impact and consequences. Australian Journal of Learning Difficulties, 23(2), 107-135. http://doi.org/10.1080/19404158.2 018.1479975 
Maul, A. (2017). Rethinking traditional methods of survey validation. Measurement. Interdisciplinary Research and Perspectives, 15(2), 51-69. https://doi.org/10.1080/15366367.2017.1348108

Mavletova, A., Couper, M. P. og Lebedev, D. (2018). Grid and item-by-item formats in PC and mobile web surveys. Social Science Computer Review, 36(6), 647-668. https://doi.org/10.1177\%2F0894439317735307

Menntamálastofnun. (e.d.). PISA-könnunin. https://mms.is/pisa-konnunin

Menntamálastofnun. (2019). PISA 2018: Helstu niðurstöður á Íslandi. http://hdl.handle.net/10802/29007

OECD. (e.d.). PISA 2018 technical report. https://www.oecd.org/pisa/data/pisa2018technicalreport/

OECD. (2019). PISA 2018 Results: What students know and can do. https://doi.org/10.1787/5f07c754-en

Revilla, M. (2017). Analyzing survey characteristics, participation, and evaluation across 186 surveys in an online opt-in panel in Spain. Methods, Data, Analyses, 11(2), 135-162. https://doi.org/10.12758/mda.2017.02

Roßmann, J., Gummer, T. og Silber, H. (2018). Mitigating satisficing in cognitively demanding grid questions: Evidence from two web-based experiments. Journal of Survey Statistics and Methodology, 6(3), 376-400. https://doi.org/10.1093/jssam/smx020

Rubin, D. B. (1976). Inference and missing data. Biometrika, 63(3), 581-592.

Skólapúlsinn (e.d.). Markmið. https://skolapulsinn.is/um/?page_id=6

Yates, R. (2013). Bad mouthing, bad habits and bad, bad, boys: An exploration of the relationship between dyslexia and drug dependence. Mental Health and Substance Use, 6(3), 184-202. https://doi.org/10.1080 /17523281.2012.699460

Póroddur Bjarnason, Stefán Hrafn Jónsson, Kjartan Ólafsson, Andrea Hjálmsdóttir og Aðalsteinn Ólafsson. (2006). Heilsa og lifskjör skólanema 2006: Landshlutaskýrsla. Háskólinn á Akureyri og Lýðheilsustöð. http:// www.hbsc.is/heilsaoglifskjor_skolanema_landshlutar_2006.pdf

Hans Haraldsson og Ingibjörg Kjartansdóttir (2021)

Gagnagöt í spurningakönnunum meðal íslenskra unglinga.

Netla - Veftímarit um uppeldi og menntun: Sérrit 2021 - HBSC og ESPAD rannsóknirnar

Sótt af http://netla.hi.is/serrit/2021/HBSC_ESPAD_rannsoknir/01.pdf

DOI: https://doi.org/10.24270/serritnetla.2021.5 